\title{
ACTA SCIENTIARUM POLONORUM
}

Scientific journal (quartely), issued since 2002,

whose founder and advocate is the Conference of the Rectors of Universities

of Life Sciences

\section{Technologia Alimentaria \\ Food Science and Human Nutrition}

\author{
19(3) 2020 \\ July - September
}

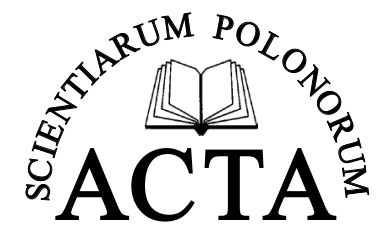

Bydgoszcz Kraków Lublin Olsztyn

Poznań Siedlce Szczecin Warszawa Wrocław 
ACTA Scientiarum Polonorum Technologia Alimentaria was founded by all Polish Agricultural Universities in 2001 and it is published by Poznań University of Life Sciences Press.

\section{Honorary Advisory Board of Acta Scientiarum Polonorum}

Józef Bieniek (University of Agriculture in Krakow), Barbara Gąsiorowska (Siedlce University of Natural Sciences and Humanities), Wojciech Gilewski (Warsaw University of Life Sciences - SGGW), Janusz Prusiński (UTP University of Science and Technology in Bydgoszcz), Julita Reguła (Poznań University of Life Sciences), Wiesław Skrzypczak (West Pomeranian University of Technology, Szczecin), Krzysztof Szkucik (University of Life Sciences in Lublin), Jerzy Sobota (Wrocław University of Environmental and Life Sciences), Ryszard Źróbek (University of Warmia and Mazury in Olsztyn)

Affiliation

Faculty of Food Science and Nutrition

Poznań University of Life Sciences, Poland

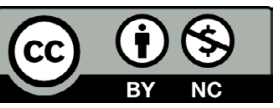

This journal is the open access and non-profit enterprise. The published papers may be collected, read and downloaded free of charge - with Author's rights reserved. We have adopted a Creative Commons licence CC BY-NC (Attribution-NonCommercial).

\section{Aim and scope}

The original scientific peer-reviewed papers published in ACTA Scientiarum Polonorum Technologia Alimentaria journal cover main aspects of food science from raw materials properties through processing aspects up to quality of final products and their nutritional properties, usability and dietetics.

It involves fundamental and applied research, including selected subjects of food science and human nutrition with pointing out at their interface.

All of these problems can be put into following topics:

\section{Food Technology}

- influence of all processing parameters on food quality and safety

- systems and methods of controlling and modification of food properties

- food biotechnology and microbiology

- any subject at the interface between food processing and food quality and human nutrition (paper connected with these technological problems are preferred)

\section{Functional Food}

- functional foods development

- production of novel food

- effects of processing and storage on the stability and biological activity of bioactive food components and their metabolites

\section{Human Nutrition}

- clinical tests of foods

- consumer preferences of standard and novel food

- diet and nutritional status assessment

- nutritional and health impacts of foods and food components

\section{Abstracting/indexing}

Web of Science Core Collection - Emerging Sources Citation Index, Medline, PubMed, Scopus, EBSCO, Food Science and Technology Abstracts ${ }^{\circledR}, \mathrm{CAB}$ International, Chemical Abstracts Service, Index Copernicus, Ulrich's Database, Directory of Open Access Journals, Agro, Agris-FAO, Embase, ProQuest, CrossRef, Scimago, HINARI, JSTOR, Socolar. 


\section{Scientific Board of Acta Scientiarum Polonorum Technologia Alimentaria}

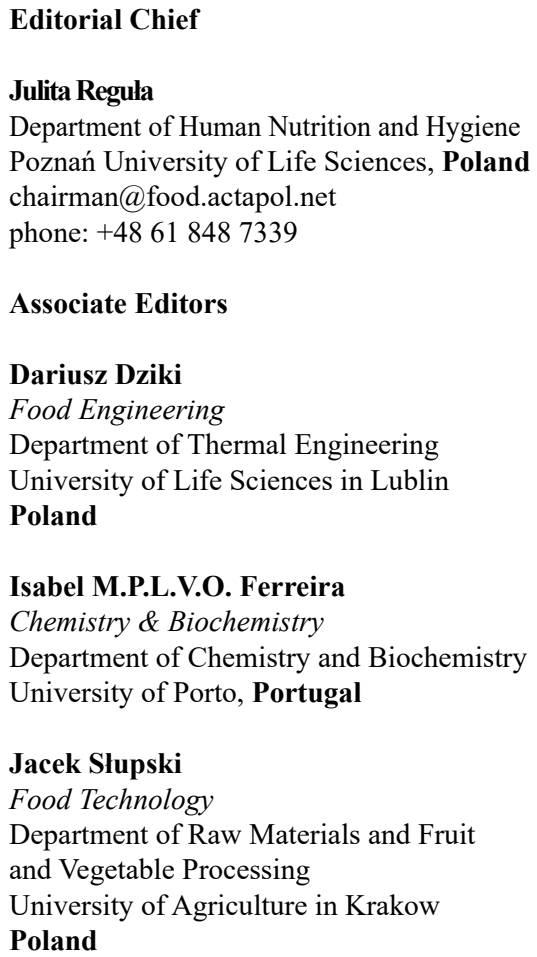

\section{Former Editors}

Waldemar Uchman - Editor in chief 2002-2015

Poznań University of Life Sciences, Poland

Zofia Lisiewska - Associate editor 2002-2015

University of Agriculture in Krakow Poland

\section{Secretary of Editorial Board}

\section{Aleksander Siger}

Poznań University of Life Sciences, Poland secretary@food.actapol.net phone: +48618487356
Members

Maria Daniel vaz de Almeida

University of Porto, Portugal

Bhaskar C. Behera

Agharkar Research Institute, India

Zbigniew Dolatowski

University of Life Sciences in Lublin Poland

Bartlomiej Dziuba

University of Warmia and Mazury in Olsztyn, Poland

Sylvian Guyot

INRA Centre de Rennes, France

Karl Heinz Herzig

University of Oulu, Finland

Berthold Victor Koletzko

University of Munich, Medical Centre Germany

Zbigniew Krejpcio

Poznań University of Life Sciences, Poland Michał Świeca

Andrea Laukova

Slovak Academy of Sciences, Slovakia

Andrzej Lenart

Warsaw University of Life Sciences SGGW, Poland

\section{Carlos Lifschitz}

Italian Hospital of Buenos Aires, Argentina

\section{Bertrand Matthäus}

Max Rubner-Institut (MRI), Germany

Abdalbasit Adam Mariod

King Abdulazis University Jeddah Saudi Arabia

\section{Paul Edward Mozdziak}

North Carolina State University, Raleigh United States

Jan Oszmiański

Wrocław University of Environmental and Life Sciences, Poland

Semih Ötles

Ege University, Turkey
Werner Praznik

University of Natural Resources and Applied Life Science, Austria

Mikołaj Protasowicki

West Pomeranian University of Technology Szczecin, Poland

Roman Przybylski

University of Lethbridge, Canada

Eddy Robberecht

Universiteit Gent, Ghent, Belgium

Kazim Sahin

Firat University, Turkey

Alexander Shleikin

St. Petersburg State University, Russia

\section{Martin Stern}

Universitätsklinikum Tübingen

Medizinische Fakultät, Tübingen

Germany

University of Life Sciences in Lublin

Poland

Alexey A. Tinkov

Orenburg State Medical Academy, Russia

Diana Thomas

University of Sydney, Australia 


\title{
Managing Team
}

\author{
Lucyna Borowczyk \\ - text editor, lucyna.borowczyk@up.poznan.pl \\ phone: +48 61848 7807, fax: +48 618487808 \\ Hanna Chudzik - statistics consultant \\ "Native English", Poznań - language correction \\ Stanisław Tuchołka - computer typesetting, panbook.pl
}

\section{Publisher and Owner}

University Publisher Poznań University of Life Sciences Press

Witosa 45, 61-693 Poznań, Poland

phone: +48 61848 7776, fax: +48 618487808

e-mail:wydawnictwo@up.poznan.pl,http://www.wydawnictwo.up-poznan.net

The papers are published in English only, in four issues yearly.

ISSN 1644-0730 (print) ISSN 1898-9594 (online)

Edition up to 60 copies. 14.5 publisher's sheets.

(C) Copyright by Wydawnictwo Uniwersytetu Przyrodniczego w Poznaniu

Print: Zakład Graficzny Uniwersytetu Przyrodniczego w Poznaniu

Wojska Polskiego 67, 60-625 Poznań 